\title{
Stress experienced by mothers of preterm newborns in a neonatal intensive care unit
}

\author{
Estresse experimentado por mães de recém-nascidos pré- \\ termo em unidade de terapia intensiva neonatal \\ Estrés experimentado por madres de recién nacidos pre- \\ termo en unidad de terapia intensiva neonatal \\ Graciela Feier Fróes ${ }^{a, b}$ \\ Eliane Norma Wagner Mendesc \\ Géssica de Almeida Pedrozac \\ Maria Luzia Chollopetz da Cunha ${ }^{a}$
}

\section{How to cite this article:}

Fróes GF, Mendes ENW, Pedroza GA,

Cunha MLC. Stress experienced by

mothers of preterm newborns in a neonatal intensive care unit. Rev Gaúcha Enferm. 2020;41(esp):e20190145. doi: https://doi.org/10.1590/19831447.2020.20190145 a Universidade Federal do Rio Grande do Sul (UFRGS). Escola de Enfermagem, Curso de Pós-Graduação em Enfermagem. Porto Alegre, Rio Grande do Sul, Brasil.

- Hospital de Clínicas de Porto Alegre (HCPA). Porto Alegre, Rio Grande do Sul, Brasil.

Universidade Federal do Rio Grande do Sul (UFRGS). Escola de Enfermagem, Curso de Graduação em Enfermagem. Porto Alegre, Rio Grande do Sul Brasil.

\begin{abstract}
Objective: To evaluate the stress level of mothers of preterm infants with gestational age $\leq 34$ weeks, hospitalized in neonatal intensive care.

Method: A cross-sectional study with 74 mothers of premature infants in neonatal intensive care, who answered the"Parental Stress Scale: Neonatal Intensive Care Unit" instrument, validated in Brazil.

Results: The mean stress level was $4.41( \pm 0.77)$ and the general stress level was $4.36( \pm 0.76)$, with a significant difference ( $p$ $<0.001$ ) between the subscale "Alteration in parental roles" and other subscales, meaning that mothers were in a very stressful situation.

Conclusion: All items in the subscale "Alteration in parental roles" of the "Parental Stress Scale: Neonatal Intensive Care Unit" were identified as the main source of stress experienced by mothers. This study suggests carrying out further studies with other methodologies to increase the knowledge of maternal stress in the national context, applying care interventions involving the parents. Keywords: Infant, premature. Intensive care units, neonatal. Stress, psychological.
\end{abstract}

\section{RESUMO}

Objetivo: Avaliar o nível de estresse de mães de recém-nascidos pré-termo com idade gestacional $\leq 34$ semanas, internados em terapia intensiva neonatal.

Método: Estudo transversal com 74 mães de recém-nascidos pré-termo em unidade de terapia intensiva neonatal, que responderam ao instrumento "Parental Stress Scale: Neonatal Intensive Care Unit", validado no Brasil.

Resultados: Obteve-se média de nível de ocorrência de estresse 4,41 ( $\pm 0,77)$ e nível geral de estresse do ambiente 4,36 $( \pm 0,76)$, com diferença significativa $(p<0,001)$ entre a subescala "Alteração no papel de pais" e demais subescalas. Significando que as mães se encontravam numa situação muito estressante.

Conclusão: Identificaram-se todos os itens da subescala "Alteração do papel de pais" da "Parental Stress Scale: Neonatal Intensive Care Unit" como a principal fonte de estresse experimentada pelas mães. Sugere-se a realização de estudos com outras metodologias para ampliar o conhecimento do estresse materno no contexto nacional, aplicando intervenções de cuidado envolvendo os pais.

Palavras-chave: Recém-nascido prematuro. Unidades de terapia intensiva neonatal. Estresse psicológico.

\section{RESUMEN}

Objetivo: Evaluar el nivel de estrés de madres de recién nacidos prematuros con edad gestacional $\leq 34$ semanas, internados en terapia intensiva neonatal.

Metódo: Estudio transversal con 74 madres de recién nacidos prematuros en unidad de terapia intensiva neonatal, que respondieron al instrumento "Parental Stress Scale: Neonatal Intensive Care Unit" validado en Brasil.

Resultados: Se obtuvo un promedio de nivel de ocurrencia de estrés $4,41( \pm 0,77)$ y nivel general de estrés del ambiente 4,36 ( \pm $0,76)$, con diferencia significativa $(p<0,001)$ entre la subescala" (Cambio en el papel de padres"y demás subescalas. Significando que las madres se encontraban en una situación muy estresante.

Conclusión: Se identificaron todos los elementos de la subescala "Cambio del papel de padres" de "Parental Stress Scale: Neonatal Intensive Care Unit" como la principal fuente de estrés experimentada por las madres. Se sugiere la realización de estudios con otras metodologías para ampliar el conocimiento del estrés materno en el contexto nacional, aplicando intervenciones de cuidado involucrando a los padres.

Palabras clave: Recien nacido prematuro. Unidades de cuidado intensivo neonatal. Estrés psicológico. 


\section{口 INTRODUCTION}

Premature birth is a traumatic event for parents. A study conducted to assess the stress of parents of preterm newborn infants (PNI) admitted to a neonatal intensive care unit (NICU) concluded that mothers had higher levels of stress than the fathers ${ }^{(1)}$.

Despite NICU being a sector with specialized care required by the preterm infants, this unexpected condition causes parents to move away from the reality they idealized and to experience parenting in an environment with bright lights, constant noise, and repeated interventions that interrupt the baby sleep cycle (PMT) and often result in discomfort or pain ${ }^{(2)}$.

Moderate to extreme prematurity of the newborn are implied by an NICU hospitalization, which compromises family interaction and may potentiate feelings related to parental stress. Thus, there is a need to identify these manifestations and relate them to the potential stressors that act on the emotions of parents who, regarding this experience, are also premature. The importance of assessing maternal well-being can be explained by a study that followed mothers and preterm infants up to 18 months of corrected age, where maternal stress levels experienced during hospitalization negatively reflected on child development and on the bond between mother an baby ${ }^{(3)}$. It is also stated that the stress expressed by mothers regarding the birth and hospitalization of their PNI in NICUs is more intense and may impact the way they relates to the infants. In addition, a higher level of stress is related to the need for mediation between professional activities and sharing with parental care, the prolonged stay of these mothers with their PNI in the NICU, as well as their biological and social role ${ }^{(4)}$.

Recognizing that premature birth is related to higher severity indicators like prolonged NICU permanence and early separation of the mother-child binomial, some researchers have been inclined to investigate ways of identifying and assessing the level of parental stress generated due to this demand in order to attend the mother in her real needs ${ }^{(5)}$.

As a method for measuring parental stress, the "Parental Stress Scale: Neonatal Intensive Care Unit — PSS: NICU" scale ${ }^{(6)}$ was developed to guide nurses actions designed to help parents to cope with NICU hospitalization. The short version of this scale was translated and validated in Brazilian Portuguese, with a high degree of understanding by parents, proving to be reliable and valid for its application in the country; it obtained a Cronbach's alpha of 0.84 in internal consistency and intraclass correlation coefficient around $0.70^{(7)}$. Although recognized and validated in different countries, the PSS: NICU scale has seldom been used in Brazil or elsewhere to study exclusively the stress of fathers and mothers of infants with a younger gestational age (GA).

In view of the considerations presented above, the following research question was formulated: "What is the level of stress presented by mothers of preterm infants admitted to a NICU?". This study was designed to assess the level of stress experienced by mothers of preterm infants with gestational age $(\mathrm{GA}) \leq 34$ weeks admitted to neonatal intensive care.

\section{METHOD}

This is a cross-sectional study, whose participants were mothers of preterm infants who responded to the PSS: NICU instrument, validated in Brazil. The study was conducted at the NICU of a university hospital in Porto Alegre, Rio Grande do Sul, Brazil. The NICU has 20 level III beds, being a reference for high risk in neonatology. In the NICU, the newborns' parents have free access and can stay with the newborns for unlimited time, 24 hours a day, seven days a week.

The sample consisted of mothers of preterm infants with $G A \leq 34$ weeks who were admitted to the NICU from November/2017 to August/2018. Mothers of preterm infants born at the Obstetric Center and admitted to the NICU within the first 72 hours of life were included. The instruments were applied only once, from the fifth to the fourteenth day of hospitalization at the NICU. The choice of this period was based on recommendations of previous studies and previous averages of preterm infants' admission to the unit where the study was conducted. The literature points out to the fact that moments close to admission and discharge of preterm infants may alter maternal stress levels in antagonistic ways, and point out a possible measurement bias ${ }^{(3,8)}$. Mothers younger than 18 years old; who were unavailable to accompany the child during hospitalization; and whose baby had dysmorphic congenital malformations of high morbidity and mortality, were excluded. In the sample size calculation, to estimate the average maternal stress, the average stress score of parental stress related to preterm infants between 28 and 36 weeks of gestational age was 2.36 with a standard deviation of 0.86 , in the "Baby Looks and Behaves" subitem, which was used as a reference ${ }^{(9)}$. Considering a $95 \%$ confidence level, a standard deviation of 0.86 and an error of 0.2 , the minimum sample size was 74 mothers of preterm infants, calculated with the aid of WINPEPI v11.43 software. Data collection began after the research was approved by 
the Institution's Ethics Committee, under CAEE number 77449317.0.0000.5327. The mothers participating in the study were invited to participate and, after signing the consent form, the data were collected.

The dependent variable of the study was maternal stress measured by the PSS: NICU scale, which addresses daily experiences that have the potential of generating parental stress during NICU admission. It has 26 items grouped into three subscales: "Sounds and images", "Appearance and infant's behavior" and "Alteration in parental roles". To answer the questionnaire, the mothers were instructed to use the PSS: NICU Likert psychometric scale to measure their perception of the experiences contained in each item, in which the value 1 represents absence of stress; 2, mild stress; 3 , moderate stress; 4, high stress; 5, extreme stress; and NA corresponds to a situation that did not happen to the mother until that moment ${ }^{(7)}$.

The author of the PSS: NICU scale guides how to perform the calculation of Metrics 1, 2 and 3 in the original $\operatorname{article}^{(6)}$. In this study, the researchers chose to use the Microsoft Excel Software to obtain the values related to stress levels and their averages, so it was necessary to elaborate mathematical expressions compatible with the software language (Image 1).

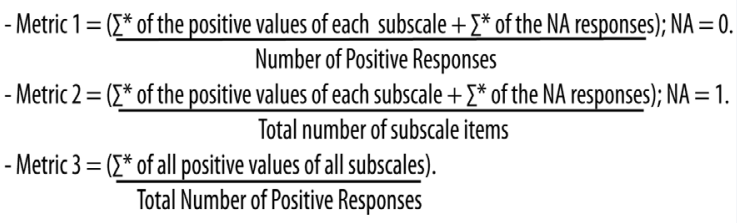

Figure 1 - Mathematical Expressions for Metrics Calculation * summation

For the maternal stress analysis, these values were grouped into three categories: 1- Not Stressful and Mildly Stressful; 2- Moderate, Very and Extremely Stressful; and 3Did not go through the experience. Regarding the data presented in Table 2, it is noteworthy that the maternal responses grouped in category 2 (Moderate, Very and Extremely Stressful) were considered by the authors as the most expressive in the analysis of Metrics 1 and 2, with values above $75 \%$. The independent variables were maternal demographic and clinical data (Table 1) and preterm infant data, which was obtained by consulting the medical records up to the point the scale was applied; in addition to the data collected by a questionnaire applied to the mothers. Each mother required about 30 minutes to answer the instruments.
For data analysis, the statistical software SPSS version 22.0 was used. Descriptive analysis of continuous variables was performed through mean and standard deviation for the variables with symmetrical or by median and interquartile range for those with asymmetric distribution. Nominal and ordinal data were described by absolute and relative frequencies. An analysis of variance (ANOVA) for repeated measures with Bonferroni adjustment was applied to compare stress levels between the subscales. The average occurrence of maternal stress for each item of the scale was calculated according to the recommendations of Metric 1, the answers marked by the mothers as not experienced received a value of zero.

Inferential statistics were used to assess the associations of demographic and clinical data of mothers during pregnancy and childbirth; gestational age, weight and nutritional status at birth of preterm infants with the average stress levels from Metrics 2 and 3, since both take into account all potentially stress-generating experiences in the NICU environment. To compare means, the Student's t-test or Analysis of Variance (ANOVA) supplemented by Tukey was applied. To perform the association tests, the variables considered were the frequently identified as influencing parental stress levels. Of the variables tested in the bivariate analysis, those with $p<0.20$ were considered to enter the Multivariate Linear Regression test to control confounding factors. The variables that entered the multivariate model in association with the overall stress levels of Metric 2 were: mother's previous experience with prematurity, GA, getting into a kangaroo position in the NICU, and maternal occupation. The variables that entered the multivariate model in association with the overall stress levels of Metric 3 were: twin pregnancy, mothers' previous experiences with $\mathrm{PNI}$, and newborn birth weight. The adopted significance level was $5 \%(p<0.05)$.

\section{RESULTS}

A total of 91 mothers had 102 newborns with GA $\leq 34$ weeks admitted to the NICU from November 7, 2017 to August 23, 2018. Among the 91 mothers, 17 and their respective newborns did not meet the eligibility criteria: the preterm infant of one of them died before the 5th day of life; four were under 18 years old; two were also in intensive care during the stipulated collection period; four were mothers of preterm infants with severe congenital malformations; and six refused to participate in the study. The sample included 74 mothers and 85 preterm infants; nine mothers had twins, and one, triplets. 
Table 1 - Characteristics of Mothers of preterm newborns admitted to a Neonatal Intensive Care Unit ( $\mathrm{n}=74$ ). Porto Alegre/ RS, 2019

\section{Characteristics \\ $n^{*}(\%)$}

\section{Age}

$<35$ years

$53(71.62)$

\section{Mother educational level}

Under 9 years

$9-\mid 12$ years

12 years or more

\section{Marital status}

With companion

Without companion

\section{Ocupation}

Maids

Without a job/Housewives

\section{Previous pregnancies}

\begin{tabular}{|c|c|}
\hline $1-3$ children & 29 (39.19) \\
\hline 3 or more children & $14(18.92)$ \\
\hline Without living children & $38(51.40)$ \\
\hline \multicolumn{2}{|l|}{ Present gestation } \\
\hline First gestation & $31(41.89)$ \\
\hline Planned gestation & $34(45.95)$ \\
\hline Twins & $10(13.51)$ \\
\hline \multicolumn{2}{|l|}{ GA at birth } \\
\hline Under 28 weeks & $15(20.27)$ \\
\hline $28-132$ weeks & $24(32.43)$ \\
\hline 32 - 34 weeks & $35(47.30)$ \\
\hline Cesarean & $50(67.57)$ \\
\hline Gestational pathologies & $51(68.92)$ \\
\hline Gestational hypertension & 23(31.08) \\
\hline Gestational Diabetes & 14(18.92) \\
\hline Infections during gestation & $15(20.27)$ \\
\hline Preeclampsia & $16(21.62)$ \\
\hline
\end{tabular}


The average maternal age was $29 \pm 7$ years. Of the total of participants, 17 (23\%) mothers had previous experience with prematurity and nine (12.2\%) had previous experience with neonatal intensive care. Regarding the current pregnancy, 64 (86.49\%) had one child, nine (12.16\%) had two children, and one (1.35\%) had three children without assisted reproduction. When included in the study, all mothers had their preterm infants included in the Kangaroo Method from the first day of life and at the time of PSS: NICU and questionnaire application, 71 (95.90\%) had initiated gentle touch, 43 (58.10\%) had placed the preterm in the kangaroo position and 14 (18.90\%) provided hygiene or comfort care.

Regarding the characteristics of the 85 preterms: 45 (52.90\%) were male; 16 (18.82\%) had less than 28 weeks of GA; 30 (35.30\%) were from 28 to less than 32 weeks of GA and 39 (45.88\%) were from 32 to 34 weeks of GA. Regarding birth weight: 22 (25.90\%) had under 1000g; 26 (30.60\%) from $1000 \mathrm{~g}$ to $1499 \mathrm{~g}$ and 37 (43.50\%) from
$1500 \mathrm{~g}$ to $2500 \mathrm{~g}$. Regarding the therapies used by PTNBs from birth to the time of application of the PSS scale: NICU: 70 (82.35\%) used total parenteral nutrition; 68 (80.0\%) had central venous access; 61 (71.76\%) used humidified incubators; 77 (90.58\%) multiparameter monitor; 79 (92.94\%) received tube diet and 62 (72.94\%) received phototherapy. In addition, 70 (82.35\%) needed some type of resuscitation maneuver in the delivery room, 77 (90.59\%) required ventilator support for at least 24 hours. Regarding the length of stay of the preterm infants, a median of 20 days (interquartile range $=10-42$ ) in the NICU was found.

The means of occurrence of maternal stress (Metric 1) and the general level of environmental stress (Metric 2) and the respective absolute and relative values of each scale item, evaluating each potentially stressful experience, are presented in Table 2.

The stress that mothers experienced according to their PSS: NICU scores was represented by the means of the three Metrics (Table 3).

Table 2 - Mean of Stress Occurrence Level (Metric 1) and Overall Environmental Stress Level (Metric 2) with relative values of maternal responses by scale item, grouped into three categories (1 - Not stressful and Mildly Stressful / 2 - Moderate, Very and Extremely Stressful / 3 - Not experienced). Porto Alegre/RS, 2019

\begin{tabular}{|c|c|c|c|c|c|c|c|}
\hline & \multicolumn{3}{|c|}{ METRIC 1* } & \multicolumn{4}{|c|}{ METRIC $2^{+}$} \\
\hline & & Category 1 & Category 2 & & Category 1 & Category 2 & Category 3 \\
\hline & $\begin{array}{l}\text { Level of } \\
\text { occurrence } \\
\text { of stress }\end{array}$ & $\begin{array}{l}\text { Not stressful } \\
\text { and Mildly } \\
\text { Stressful }\end{array}$ & $\begin{array}{c}\text { Moderate/ } \\
\text { High/ } \\
\text { Extreme } \\
\text { stress }\end{array}$ & $\begin{array}{l}\text { General } \\
\text { level of } \\
\text { stress }\end{array}$ & $\begin{array}{l}\text { Not stressful } \\
\text { and Mildly } \\
\text { Stressful }\end{array}$ & $\begin{array}{c}\text { Moderate/ } \\
\text { High/ } \\
\text { Extreme } \\
\text { stress }\end{array}$ & $\begin{array}{l}\text { Did not go } \\
\text { through the } \\
\text { experience }\end{array}$ \\
\hline SUBSCALE & Mean (SD) & $n^{\mp}(\%)$ & $\mathbf{n}^{\ddagger}(\%)$ & Mean (SD) & $\mathbf{n}^{\neq}(\%)$ & $\mathbf{n}^{\neq}(\%)$ & $\mathrm{n}^{\ddagger}(\%)$ \\
\hline
\end{tabular}

SOUNDS AND IMAGES

\begin{tabular}{|c|c|c|c|c|c|c|c|}
\hline $\begin{array}{l}\text { The presence of monitors } \\
\text { and equipment }\end{array}$ & $2.97( \pm 1.43)$ & $31(41.9)$ & $43(58.1)$ & $2.97( \pm 1.42)$ & 31 (41.9) & $43(58.1)$ & $0(00.0)$ \\
\hline $\begin{array}{l}\text { The constant noise of } \\
\text { monitors and equipment }\end{array}$ & $2.78( \pm 1.42)$ & $33(45.2)$ & $40(54.8)$ & $2.76( \pm 1.41)$ & $33(44.6)$ & $40(54.0)$ & $1(01.4)$ \\
\hline $\begin{array}{l}\text { The sudden noise of the } \\
\text { monitor alarm }\end{array}$ & $3.42( \pm 1.39)$ & $21(28.8)$ & $52(71.2)$ & $3.39( \pm 1.40)$ & 21 (28.4) & $52(70.2)$ & $1(01.4)$ \\
\hline $\begin{array}{l}\text { The other sick babies in the } \\
\text { room }\end{array}$ & $2.32( \pm 1.28)$ & $43(58.1)$ & $31(41.9)$ & $2.32( \pm 1.27)$ & $43(58.1)$ & $31(41.9)$ & $0(0.0)$ \\
\hline $\begin{array}{l}\text { The large number of people } \\
\text { working in the unit }\end{array}$ & $1.70( \pm 1.28)$ & $58(79.5)$ & 15 (20.5) & $1.69( \pm 1.26)$ & $58(78.3)$ & 15 (20.3) & $1(01.4)$ \\
\hline $\begin{array}{l}\text { Watching a machine } \\
\text { (ventilator) breathe for my } \\
\text { baby }\end{array}$ & $4.00( \pm 1.36)$ & $12(18.2)$ & $54(81.8)$ & $3.68( \pm 1.58)$ & $12(16.2)$ & $54(73.0)$ & $8(10.8)$ \\
\hline \multicolumn{8}{|c|}{ BABY APPEARANCE AND BEHAVIOR } \\
\hline $\begin{array}{l}\text { Tubes and equipment on or } \\
\text { near my baby }\end{array}$ & $3.81( \pm 1.27)$ & $13(17.8)$ & $60(82.2)$ & $3.77( \pm 1.29)$ & 13 (17.6) & $60(81.0)$ & $1(01.4)$ \\
\hline
\end{tabular}




\begin{tabular}{|c|c|c|c|c|c|c|c|}
\hline & \multicolumn{3}{|c|}{ METRIC 1* } & \multicolumn{4}{|c|}{ METRIC $2^{+}$} \\
\hline & & Category 1 & Category 2 & & Category 1 & Category 2 & Category 3 \\
\hline & $\begin{array}{l}\text { Level of } \\
\text { occurrence } \\
\text { of stress }\end{array}$ & $\begin{array}{l}\text { Not stressful } \\
\text { and Mildly } \\
\text { Stressful }\end{array}$ & $\begin{array}{c}\text { Moderate/ } \\
\text { High/ } \\
\text { Extreme } \\
\text { stress } \\
\end{array}$ & $\begin{array}{l}\text { General } \\
\text { level of } \\
\text { stress }\end{array}$ & $\begin{array}{l}\text { Not stressful } \\
\text { and Mildly } \\
\text { Stressful }\end{array}$ & $\begin{array}{c}\text { Moderate/ } \\
\text { High/ } \\
\text { Extreme } \\
\text { stress } \\
\end{array}$ & $\begin{array}{l}\text { Did not go } \\
\text { through the } \\
\text { experience }\end{array}$ \\
\hline SUBSCALE & Mean (SD) & $n^{\ddagger}(\%)$ & $\mathbf{n}^{\ddagger}(\%)$ & Mean (SD) & $\mathbf{n}^{\ddagger}(\%)$ & $\mathbf{n}^{\ddagger}(\%)$ & $\mathbf{n}^{\ddagger}(\%)$ \\
\hline $\begin{array}{l}\text { My baby's bruises, cuts } \\
\text { or injuries }\end{array}$ & $3.73( \pm 1.51)$ & $16(25.8)$ & $46(74.2)$ & $3.28( \pm 1.70)$ & $16(21.6)$ & $46(62.2)$ & $12(16.2)$ \\
\hline $\begin{array}{l}\text { The abnormal color of my } \\
\text { baby (for example: pale } \\
\text { or yellowish) }\end{array}$ & $3.02( \pm 1.48)$ & $24(39.3)$ & $37(60.7)$ & $2.66( \pm 1.54)$ & $24(32.4)$ & $37(50.0)$ & $13(17.6)$ \\
\hline $\begin{array}{l}\text { Unusual or abnormal } \\
\text { breathing from my baby }\end{array}$ & $4.05( \pm 1.25)$ & $11(16.7)$ & $55(83.3)$ & $3.72( \pm 1.50)$ & $11(14.9)$ & $55(74.3)$ & $8(10.8)$ \\
\hline My baby's small size & $3.25( \pm 1.45)$ & $24(32.9)$ & $49(67.1)$ & $3.22( \pm 1.45)$ & $24(32.4)$ & $49(66.2)$ & $1(01.4)$ \\
\hline The wrinkled look of my baby & $2.17( \pm 1.22)$ & $40(61.5)$ & $25(38.5)$ & $2.03( \pm 1.20)$ & $40(54.0)$ & $25(33.8)$ & $9(12.2)$ \\
\hline $\begin{array}{l}\text { Seeing needles and tubes } \\
\text { in my baby }\end{array}$ & $4.06( \pm 1.23)$ & $10(14.3)$ & $60(85.7)$ & $3.89( \pm 1.37)$ & $10(13.6)$ & $60(81.0)$ & $4(05.4)$ \\
\hline $\begin{array}{l}\text { My baby being fed through } \\
\text { a vein or a tube }\end{array}$ & $3.99( \pm 1.19)$ & $8(11.1)$ & $64(88.9)$ & $3.91( \pm 1.26)$ & $8(10.8)$ & $64(86.5)$ & $2(02.7)$ \\
\hline $\begin{array}{l}\text { When my baby seemed to } \\
\text { be in pain }\end{array}$ & $4.23( \pm 1.32)$ & $8(12.3)$ & $57(87.7)$ & $3.84( \pm 1.62)$ & $8(10.8)$ & $57(77.0)$ & $9(12.2)$ \\
\hline \multicolumn{8}{|c|}{ BABY APPEARANCE AND BEHAVIOR } \\
\hline When my baby looked sad & $4.07( \pm ., 36)$ & $10(16.9)$ & $49(83.1)$ & $3.45( \pm 1.73)$ & $10(13.6)$ & $49(66.1)$ & $15(20.3)$ \\
\hline $\begin{array}{l}\text { My baby's flabby and } \\
\text { fragile look }\end{array}$ & $3.64( \pm 1.42)$ & $16(23.2)$ & $53(76.8)$ & $3.46( \pm 1.52)$ & $16(21.6)$ & $53(71.6)$ & $5(06.8)$ \\
\hline $\begin{array}{l}\text { My baby's restless, makes } \\
\text { restless movements }\end{array}$ & $3.25( \pm 1.55)$ & $26(36.6)$ & $45(63.4)$ & $3.16( \pm 1.57)$ & $26(35.1)$ & $45(60.8)$ & $3(04.1)$ \\
\hline $\begin{array}{l}\text { My baby not being able to } \\
\text { cry like the other babies }\end{array}$ & $3.15( \pm 1.67)$ & $24(39.3)$ & $37(60.7)$ & $2.77( \pm 1.71)$ & $24(32.4)$ & $37(50.0)$ & $13(17.6)$ \\
\hline \multicolumn{8}{|c|}{ ALTERATION IN PARENTAL ROLES } \\
\hline $\begin{array}{l}\text { Being separated from my } \\
\text { baby }\end{array}$ & $4.66( \pm 0.86)$ & $4(5.4)$ & $70(94.6)$ & $4.66( \pm 0.86)$ & $4(5.4)$ & $70(94.6)$ & $0(00.0)$ \\
\hline $\begin{array}{l}\text { Not feeding my } \\
\text { baby myself }\end{array}$ & $4.56( \pm 0.80)$ & $2(2.7)$ & $71(97.3)$ & $4.51( \pm 0.89)$ & $2(2.7)$ & $71(95.9)$ & $1(01.4)$ \\
\hline $\begin{array}{l}\text { Not being able to } \\
\text { take care of my baby } \\
\text { myself (e.g. changing } \\
\text { diapers, bathing) }\end{array}$ & $4.27( \pm 1.01)$ & $5(7.1)$ & $65(92.9)$ & $4.09( \pm 1.22)$ & $5(6.8)$ & $65(87.8)$ & $4(05.4)$ \\
\hline $\begin{array}{l}\text { Not being able to hold my } \\
\text { baby when I want }\end{array}$ & $4.53( \pm 1.01)$ & $5(6.9)$ & $67(93.1)$ & $4.43( \pm 1.14)$ & $5(6.8)$ & $67(90.5)$ & $2(02.7)$ \\
\hline $\begin{array}{l}\text { Feeling helpless and unable } \\
\text { to protect my baby from } \\
\text { pain and painful procedures }\end{array}$ & $4.61( \pm 0.91)$ & $3(4.2)$ & $69(95.8)$ & $4.51( \pm 1.07)$ & $3(4.1)$ & $69(93.2)$ & $2(02.7)$ \\
\hline $\begin{array}{l}\text { Feeling unable to help my } \\
\text { baby during this time }\end{array}$ & $4.57( \pm 0.96)$ & $5(6.9)$ & $67(93.1)$ & $4.47( \pm 1.11)$ & $5(6.8)$ & $67(90.5)$ & $2(02.7)$ \\
\hline
\end{tabular}




\begin{tabular}{|c|c|c|c|c|c|c|c|}
\hline & \multicolumn{3}{|c|}{ METRIC $1 *$} & \multicolumn{4}{|c|}{ METRIC $2^{+}$} \\
\hline & & Category 1 & Category 2 & & Category 1 & Category 2 & Category 3 \\
\hline & $\begin{array}{l}\text { Level of } \\
\text { occurrence } \\
\text { of stress }\end{array}$ & $\begin{array}{l}\text { Not stressful } \\
\text { and Mildly } \\
\text { Stressful }\end{array}$ & $\begin{array}{c}\text { Moderate/ } \\
\text { High/ } \\
\text { Extreme } \\
\text { stress }\end{array}$ & $\begin{array}{l}\text { General } \\
\text { level of } \\
\text { stress }\end{array}$ & $\begin{array}{c}\text { Not stressful } \\
\text { and Mildly } \\
\text { Stressful }\end{array}$ & $\begin{array}{c}\text { Moderate/ } \\
\text { High/ } \\
\text { Extreme } \\
\text { stress }\end{array}$ & $\begin{array}{l}\text { Did not go } \\
\text { through the } \\
\text { experience }\end{array}$ \\
\hline SUBSCALE & Mean (SD) & $\mathbf{n}^{\ddagger}(\%)$ & $n^{\ddagger}(\%)$ & Mean (SD) & $n^{\ddagger}(\%)$ & $n^{\ddagger}(\%)$ & $n^{\ddagger}(\%)$ \\
\hline $\begin{array}{l}\text { Not having time to be } \\
\text { alone with my baby }\end{array}$ & $3.90( \pm 1.48)$ & $15(20.8)$ & $57(79.2)$ & $3.82( \pm 1.53)$ & $15(20.3)$ & $57(77.0)$ & $2(02.7)$ \\
\hline
\end{tabular}

Source: Research data, 2019.

* Metric 1 corresponds to the level of stress occurrence for each subcategory, does not attribute value to experiences not experienced by the mother, the $n$ varies in each item of the scale.

† Metric 2 corresponds to the general level of environmental stress for each subcategory, assigning value $=1$ for experiences not perceived by the mother, $n=74$ in all items on the scale. ‡ individuals' number

Table 3 - Means and standard deviations of Stress Levels of each subscale and total scale. Porto Alegre/RS, 2019

\begin{tabular}{|c|c|c|c|c|c|}
\hline & $\begin{array}{c}\text { Metric }{ }^{*} \\
\text { Stress occurrence } \\
\text { level }\end{array}$ & $p^{\S}$ & $\begin{array}{l}{\text { Metric } 2^{\dagger}}^{\text {General Stress Level }} \\
\text { of the environment }\end{array}$ & $\mathbf{p}^{\S}$ & $\begin{array}{c}\text { Metric } 3^{\ddagger} \\
\text { Total number } \\
\text { of stress } \\
\text { experiences }\end{array}$ \\
\hline $\begin{array}{l}\text { SUBSCALES } \\
\text { SUL }\end{array}$ & $\mathbf{M}(S D)$ & & $M(S D)$ & & $\mathbf{M}(S D)$ \\
\hline Sound and images & $2.84( \pm 0.90)^{\mathrm{a}^{* *}}$ & & $2.80( \pm 0.90)^{\mathrm{a}^{* *}}$ & & .. \\
\hline Baby appearance and behavior & $3.55( \pm 0.92)^{b^{* *}}$ & $<0.001$ & $3.32( \pm 0.93)^{b^{* *}}$ & $<0.001$ & .. \\
\hline Changes in parental roles & $4.41( \pm 0.77)^{\mathrm{c}^{* *}}$ & & $4.36( \pm 0.76)^{c^{* *}}$ & & .. \\
\hline $\begin{array}{l}\text { Scale total level of } \\
\text { stress }\end{array}$ & & & & & $3.62( \pm 0.88)$ \\
\hline
\end{tabular}

Source: Research data, 2019.

* Metric 1 corresponds to the level of stress occurrence for each subcategory, does not attribute value to experiences marked as not experienced by the mother.

+ Metric 2 corresponds to the general level of environmental stress for each subcategory, assigning value $=1$ for experiences marked as not experienced by the mother.

¥ Metric 3 corresponds to the total level of stress experiences measured by the scale from the affirmative answers found in the three subcategories.

§ ANOVA test for repeated measures.

${ }^{* *}$ a, b, c - equal letters do not differ by Bonferroni test at $5 \%$ significance.

The association between the dependent variable (general levels of maternal stress for each subscale - Metric 2) and the independent variables was performed. It was evidenced that, in the subscale "Appearance and Behavior of the Baby", mothers who had no previous experience with prematurity had significantly higher stress scores ( $p$ $=0.030$ ) than mothers who had already had a premature child. The other associations were not significant.

In the association between the dependent variable (general level of maternal stress for the total scale - Metric 3) and the independent variables, the result was not significant in the tested variables. However, in the multivariate analysis, with the metric 3 stress scores, when adjusted for twins, mothers with previous experience with prematurity had lower overall stress levels than those without previous experience $(b=-0.54 ; 95 \% \mathrm{Cl}$ : -1.0 to -0.04; $p=0.036)$.

When the multivariate analysis was performed after adjustment for prior experience in prematurity, previous ICU experience and gestational age, mothers of extremely premature infants with birth weight $<1000 \mathrm{~g}$ had a significantly lower score on overall stress levels by metric 3 ( $b=$ -0.49 ; $95 \% \mathrm{Cl}$ : -0.93 to $-0.04 ; \mathrm{p}=0.034)$. When associating GA with the beginning of the kangaroo position, it was found that the lower the gestational age, the lower the mother's contact with the preterm infants in the kangaroo position (87.2\% of moderate premature, $43.3 \%$ of very premature and $12,5 \%$ of extremely premature; $p<0.001$ ). 


\section{口DISCUSSION}

By assessing the stress experienced by the 74 mothers of preterm infants with an obstetric gestational age (OGA) $\leq 34$ weeks admitted to the NICU by applying the PSS: NICU scale, the level of overall stress was perceived as very stressful (Metric 3). In this context, a cross-sectional study that assessed the level of stress in 91 fathers and 120 mothers of preterm infants, found the median of the general level of maternal stress to be a value considered very high ${ }^{(5)}$. Authors state that mothers may have their emotional health compromised when the development of parenting is modified by the unexpected hospitalization of premature infants in NICUs, as it negatively impacts on family organization, generates changes in daily routine and requires adaptation to the new role, which requires other children. responsibilities, skills and specific knowledge. Currently, it is recommended that staying longer at the bedside helps a healthier development of their parenting relationship and improves their perception of NICU stress ${ }^{(10-11)}$.

In our study, in the subscale "Changes in parental roles", the percentages of the occurrence level of moderate / very / extremely stressful (Category 2, Metric 1) and the overall stress level (Category 2, Metric 2) were higher than $75 \%$ in the seven items of this subscale. A cohort study corroborates these findings, as it showed that parents involved in routine care in the NICU showed higher levels of dissatisfaction and stress in the "Changes in parental roles" subscale than those included in a family-centered healthcare program ${ }^{(12)}$.

In the "Baby Appearance and Behavior" subscale, the level of stress occurrence (Category 2, Metric 1) was over $75 \%$ on seven items: "Tubes and equipment on or near my baby," "Unusual or abnormal breathing by my baby "," Seeing needles and tubes in my baby",' My baby being fed through a vein or a tube "','When my baby seemed to be in pain", "When my baby looked sad" and "Flabby and fragile appearance of my baby. "When analyzing the subscale for overall stress levels (Metric 2, Category 2) four items were over 75\%: "Tubes and equipment on or near my baby", "Seeing needles and tubes in my baby", "My baby being fed through a vein or a tube "and" When my baby seemed to be in pain ". A prospective study identified the most stressful elements for parents of preterm infants with $<36$ weeks in NICU were "feeling pain and the baby being sad", and the appearance of preterm infants were "bruises and cuts on the baby and the baby changing color", taking as a reference high and extreme general stress levels ${ }^{(13)}$.

In the Sounds and Images subscale, regarding the level of stress occurrence (Category 2, Metric 1), the item "Seeing a machine (respirator) breathe for my baby" was the only one to reach more than $75 \%$ of mothers referring to this experience as moderate to extremely stressful. None of the other items reached the mark of $75 \%$ mothers reporting overall stress levels (Metric 2) as moderate to extremely stressful. Regarding this data, a study on the main components of the neonatal care process from the perspective of parents, explains that mothers feel excluded from the care, especially when the baby is very premature and needs advanced technological support; it recommended health professionals to focus on facilitating maternal interactions with caregivers ${ }^{(14)}$.

Statistically significant differences were noted between stress scores found in the three subscales (Metric 1 and Metric 2). It was observed that the subscale "Changes in parental roles" presented a moderate general level of stress. A study that investigated the stress levels of 57 fathers and mothers of preterm infants under 37 weeks of age at admission and discharge found a similar trend in maternal stress in their Metric 2 results regarding the "Changes in parental roles" subscale, with moderate general stress levels ${ }^{(8)}$.

Regarding maternal characteristics, the results showed a prevalence of women under 35 years old, mostly single and with no other children. In a previous study, women were also young, but mostly married and with one child ${ }^{(8)}$. A cross-sectional study that identified sources of stress in mothers and fathers of preterm infants as associated with sociodemographic, obstetric and child characteristics reported that maternal age is not associated with stress levels ${ }^{(5)}$. The literature emphasizes the importance of a stable marital relationship and mutual support as positive influences in reducing parental stress ${ }^{(15)}$. Regarding the previous existence of other children, there is a greater experience of stress in parents who are experiencing parenting for the first time, when compared to parents with more than one child ${ }^{(16)}$.

In relation to the the characteristics of preterm infants, the male gender was more prevalent; with birth weight $<1,500 \mathrm{~g}$ and GA $<32$ weeks. Most of them had a high degree of severity, judging by the amount of technological support needed to support their life. The use of ventilatory support for at least 24 hours was necessary in $90.59 \%$ of these preterm infants. A multicenter cross-sectional study determining the level of stress in parents of very low birth weight newborns in the NICU found similar characteristics regarding the male gender (52.4\%), gestational age (29 \pm 2.6 weeks), and birth weight $(1135 \pm 268 \mathrm{~g})^{(1)}$. In addition, higher stress levels of mothers in the "Sounds and Images" subscale related to ventilator use and lower gestational age were reported. These factors are also associated with 
mothers' difficulty in bonding to their preterm infants, holding them in their laps and exercising their parental role $e^{(1,13-14)}$.

By associating the overall stress level on the full scale (Metric 3) with birth weight, we found that mothers of extremely low birth weight preterm infants had lower stress levels than mothers of very low birth weight and very low birth weight preterm infants $(p=0.024)$. Contradictorily, researches that associated parental and child characteristics with stress reported that low birth weight associated with extreme prematurity and its high medical risks may increase the level of parental stress ${ }^{(15)}$. We attributed this difference to the shorter gestational time of these mothers, difficulties in assuming their new role and establishing a closer bond with their premature infant due to the physical barrier imposed by the incubator and other life support technologies, as well as the severity of the preterm infants cases, who cannot benefit from closer contact through the kangaroo position.

When the gestational age (gestational age) of preterm infants was associated with the start of using the kangaroo position, it was found that the lower the gestational age, the lower the mother's contact with the preterm infant in the kangaroo position (87.2\% of moderate preterm infants, $43.3 \%$ of very premature, and $12.5 \%$ of extremely premature; $p<0.001)$. Regarding the Kangaroo Method, there was no significant difference (Sounds and image $p=0.519$; Appearance and behavior of the baby $p=0.415$; and Change in parental roles $p=0.648$ ) regarding the beginning of the kangaroo position. However, stress levels in the three subscales were higher in mothers who had not yet taken the kangaroo position with their preterm infant. A study points out that skin-to-skin contact in the kangaroo position has a positive effect on the mother-baby interaction and on the maternal mood ${ }^{(17)}$. In addition, in an observational study introducing innovative kangaroo positioning, the stress scores obtained by PSS: NICU were lower in the group that practiced the new kangaroo positioning method for the "Sounds and Imaging" and "Appearance and Behavior" subscales. However, these differences were not significant ${ }^{(18)}$.

Regarding the "Appearance and Behavior of the Baby" subscale, mothers who had no previous experience with prematurity had significantly higher stress scores $(p=0.030)$ than mothers who had already had a premature child. A similar result was reported in a cross-sectional study in which mothers with no previous experience with NICU admission had higher stress scores in all PSS: NICU subscales ${ }^{(5)}$. A study that investigated the effect of relaxation techniques combined with an information-based intervention on stress and anxiety in parents with hospitalized preterm infants, demonstrated a significant reduction in the anxiety variable of mothers and fathers ${ }^{(19)}$. Authors have recommended that stress-induced symptoms in mothers, with or without previous experience of having a premature infant admitted to an NICU, may be alleviated by: applying relaxation techniques; work methodologies that allow for greater family participation; mothers participation in support groups between parents in similar situations; psychological support; and more effective communication between mother and nurses ${ }^{(12-14,19-20)}$.

Regarding limitations, it was difficult to establish comparisons of the results of the present study with national literature, since there is still little research in the area of parental stress using the validated PSS: NICU scale in Brazil. The fact that the investigation happened in a single health institution is also a limitation of the study, since the sample, despite being representative, was restricted to a group of mothers and professionals from the same region, with specific habits and dynamics.

\section{$\square$ CONCLUSION}

From the results found, it was identified that the subscale "Changes in parental roles" of PSS: NICU was the main source of stress experienced by the mothers of this study.

It is known that the use of the best practices related to family-centered care results in actions that cooperate for the development of autonomy and safety in the performance of the parental role. They include the guarantee of free access to the mother, the father and their relatives by the responsible for the NICU; open dialogue with them, listening to their views on their treatment; making it easier to access information about the PTNB. Nevertheless, it is clear that the high levels of stress pointed out by mothers in the "Changing the Role of Parents" subscale could be alleviated if NICU teams were closer to parents and family so that family-centered care methodologies could be more effective by strengthening parental participation in PTNB care.

It is concluded that it is essential that nurses, in addition to assessing parental stress, resort to a set of attitudes and practices to empower mothers, so that they perceive themselves as essential to their premature infants. Helping the mother to experience premature motherhood safely, developing skills to care for the premature infants in the $\mathrm{NICU}$, establishing a daily relationship that will continue to develop the attachment of the newborn and strengthening their bond with the preterm are attitudes that will bridge the gap between care, possible hospital care, and home care devised by the mothers.

This investigation recommends further studies on the stress of mothers of extremely preterm infants, increasingly present in NICUs. These mothers, due to the fragility of 
these premature infants and all the support they need to survive prolonged hospitalization, are more exposed to the stressors of intensive care, taking longer to be included in the care routine and tending to start the kangaroo position late.

\section{REFERENCES}

1. Wormald F, Tapia IL, Torres G, Cánepa P, González MA, Rodríguez D. Stress in parents of very low birth weight preterm infants hospitalized in neonatal intensive care units: a multicenter study. Arch Argent Pediatr. 2015;113(4):3038. doi: https://doi.org/10.5546/aap.2015.eng.303

2. Stacey $\mathrm{S}, 0$ sborn M, Salkovskis P. Life is a rollercoaster. . . what helps parents cope with the Neonatal Intensive Care Unit (NICU)? J Neonatal Nurs. 2015;21(4):3641. doi: https://doi.org/10.1016/j.jnn.2015.04.006

3. Holditch-Davis D, White-Traut R, Levy JA, O'Shea TM, Geraldo V, David RJ. Maternally administered interventions for preterm infants in the NICU: effects on maternal psychological distress and mother-infant relationship. Infant Behav Dev. 2014;37(4):695-710. doi: https://doi.org/10.1016/j.infbeh.2014.08.005

4. Brodsgaard A, Zimmermann R, Petersen M. A preterm lifeline: early discharge programme based on family-centred care. I Spec Pediatr Nurs. 2015;20(4)23243. doi: https://doi.org/10.1111/spn.12120

5. Baía I, Amorim M, Silva S, Kelly-lrving M, Freitas C, Alves E. Parenting very preterm infants and stress in Neonatal Intensive Care Units. Early Hum Dev. 2016;101:3-9. doi: https://doi.org/10.1016/j.earlhumdev.2016.04.001

6. Miles MS, Funk SG, Carlson J. Parental Stressor Scale: Neonatal Intensive Care Unit. Nurs Res. 1993;42(3):148-52. doi: https://doi.org/10.1097/00006199199305000-00005.

7. Souza S. Tradução, adaptação cultural e validação para a língua portuguesa da Parental Stress Scale: Neonatal Intensive Care Unit (PSS: NICU) [dissertação]. São Paulo: Universidade Federal de São Paulo; 2009.

8. Stübe M, Rosa MBC, Pretto CR, Cruz CT, Morin PV, Stumm EMF. Stress levels of newborns' parents in Neonatal Intensive Care Unit. Rev Rene. 2018;19:e3254. doi: https://doi.org/10.15253/2175-6783.2018193254

9. Dudek-Schriber L. Parent stress in the neonatal intensive care unit and the influence of parent and infant characteristics. Am J Occup Ther. 2004;58(5):50920. doi: https://doi.org/10.5014/ajot.58.5.509

10. Ahlqvist-Björkroth S, Boukydis Z, Axelin AM, Lehtonen L. Close Collaboration with Parents ${ }^{\mathrm{T}}$ intervention to improve parents' psychological well-being and child development: description of the intervention and study protocol. Behav Brain Res. 2017;325(Pt B):303-10. doi: https://doi.org/10.1016/j. bbr.2016.10.020

11. Pineda R, Bender J, Hall B, Shabosky L, Annecca A, Smith J. Parent participation in the neonatal intensive care unit: predictors and relationships to neurobehavior and developmental outcomes. Early Hum Dev. 2018 Feb;117:32-8. doi: https:// doi.org/10.1016/j.earlhumdev.2017.12.008

12. Bernardo G, Maria S, Giordano M, Sordino D, Riccitelli M. Supporting parents in taking care of their infants admitted to a neonatal intensive care unit: a prospective cohort pilot study. Ital J Pediatr. 2017;43:36. doi: https://doi. org/10.1186/s13052-017-0352-1

13. Turner M, Chur-Hansen A, Winefiles H, Stanners M. The assessment of parental stress and support in the neonatal intensive care unit using the Parent Stress Scale - Neonatal Intensive Care Unit. Women Birth. 2015;28(3):252-8. doi: https://doi.org/10.1016/j.wombi.2015.04.001

14. Ottosson C, Lantz B. Parental participation in neonatal care. J Neonatal Nurs. 2017;23(3):112-8. doi: https://doi.org/10.1016/j.jnn.2016.11.001

15. Mahon P, Albersheim S, Holsti L. The Fathers' Support Scale: Neonatal Intensive Care Unit (FSS:NICU): development and initial content validation. J Neonatal Nurs. 2015;21(2):63-71. doi: https://doi.org/10.1016/j.jnn.2014.09.007

16. Kawafha MM. Parental stress in the neonate intensive care unit and its association with parental and infant characteristics. J Neonatal Nurs. 2018;24(5):266-72. doi: https://doi.org/10.1016/j.jnn.2018.05.005

17. Herizchi S, Hosseini MB, Ghoreishizadeh M. The impact of kangaroo-mother care on postpartum depression in mothers of premature infants. Int J Women's Health Reprod Sciences. 2018:5(4):312-7. doi: https://doi.org/10.15296/ ijwhr.2017.53

18. Buil A, Caeymaex L, Mero S, Sankey C, Apter G, Devouche E. Kangaroo supported diagonal flexion positioning: positive impact on maternal stress and postpartum depression risk and on skin-to-skin practice with very preterm infants. J Neonatal Nurs. 2019;25(2):86-92. doi: https://doi.org/10.1016/j.jnn.2018.10.006

19. Fotiou C, Vlastarakos PV, Bakoula C, Papagaroufalis K, Bakoyannis G, Darviri C, Chrousos $G$. Parental stress management using relaxation techniques in a neonatal intensive care unit: a randomised controlled trial. Intensive Crit Care Nurs. 2016 Feb;32:20-8. doi: https://doi.org/10.1016/j.iccn.2015.08.006

20. Musabirema P, Brysiewicz P, Chipps J. Parents perceptions of stress in a neonatal intensive care unit in Rwanda. Curationis. 2018;38(2):1499. doi: https://doi. org/10.4102/curationis.v38i2.1499

\section{- Corresponding author:}

Graciela Feier Fróes

E-mail: gfroes@hcpa.edu.br
Received: 05.06.2019

Approved: 08.15.2019 